\title{
PHENOLOGY AND BIOMETRY OF PHYSIC NUT IN THE BRAZILIAN SAVANNAH
}

\author{
Fenologia e biometria de pinhão-manso no cerrado
}

\author{
Fábio de Lima Gurgel ${ }^{1}$, Bruno Galvêas Laviola ${ }^{2}$, Daniel Medeiros da Silva ${ }^{3}$, \\ Adilson Kenji Kobayashi ${ }^{4}$,Tatiana Barbosa Rosado
}

\begin{abstract}
Phenological studies on three morphologically distinct accessions of physic nut (Jatropha curcas L.) were conducted in the Brazilian Savannah biome. Plant growth rate, flowering, fruit formation and development were measured in order to establish appropriate management practices for increasing productivity. The accessions CNPAE-102 (toxic and susceptible to powdery mildew), CNPAE-169 (non-toxic and susceptible to powdery mildew) and CNPAE-259 (toxic and resistant to powdery mildew) were studied. Accessions with undetectable levels of phorbol ester in the grains were considered as non-toxic. The agronomic variables (plant height, number of inflorescences, number of green and ripe fruits per plant) from each accession were measured biweekly during one year (August 2009 to July 2010), correlating them with climatic variables using the Pearson's correlation analysis. CNPAE-102 showed the highest growth rate $\left(0.76 \mathrm{~cm} \mathrm{day}^{-1}\right)$, with $1.10 \mathrm{~m}$ increment in height and final height of $2.60 \mathrm{~m}$. CNPAE-169 showed the lowest growth rate $\left(0.63 \mathrm{~cm}_{\text {day }}{ }^{-1}\right)$ with final mean height of $1.85 \mathrm{~m}$. CNPAE-102 and CNPAE-259 showed early cycle and CNPAE-169, late cycle. The minimum temperature was the climatic variable that determined the most inflorescences.
\end{abstract}

Index terms: Growth rate, flowering, fruiting, temperature.

\section{RESUMO}

Estudos fenológicos de três acessos morfologicamente distintos de pinhão-manso (Jatropha curcas L.) foram conduzidos no bioma Cerrado brasileiro. A taxa de crescimento da planta, florescimento, formação e desenvolvimento dos frutos foram medidos, a fim de se estabelecer práticas de manejo eficientes para o aumento de produtividade. Os acessos estudados foram: CNPAE-102 (tóxico, susceptível a oídio), CNPAE-169 (não-tóxico, susceptível a oídio) e CNPAE-259 (tóxico, resistente a oídio). Os materiais considerados não-tóxicos não possuem ésteres de forbol detectáveis nos grãos. No período de um ano (agosto de 2009 a julho de 2010) registraram-se, quinzenalmente, as variáveis agronômicas (altura de plantas, número de inflorescências, número de frutos verdes e maduros por planta) de cada acesso, correlacionando-as com as variáveis climáticas, por meio da análise de correlação de Pearson. O acesso CNPAE-102 apresentou a maior taxa de crescimento $\left(0,76 \mathrm{~cm} \mathrm{dia}^{-1}\right)$, incremento $1,10 \mathrm{~m}$ na altura e altura final de 2,60 m; o CNPAE-169 apresentou menor incremento $\left(0,63 \mathrm{~cm} \mathrm{dia}^{-1}\right)$, atingindo altura final de $1,85 \mathrm{~m}$. Os acessos CNPAE-259 e CNPAE-102 foram os mais precoces, e o CNPAE-169 o mais tardio. A temperatura mínima foi a variável climática que determinou o maior número de inflorescências.

Termos para indexação: Taxa de crescimento, florescimento, frutificação, temperatura.

(Received in june 7, 2011 and approved in september 22, 2011)

\section{INTRODUCTION}

The Brazillian Savannah biome occupies an area of 204.7 million hectares and covers the states of Bahia, Goiás, Maranhão, Mato Grosso, Mato Grosso do Sul, Minas Gerais, Paraná, Piauí, São Paulo, Tocantins, as well Federal District, around $20 \%$ of the Brazilian territory. The vegetation is considered a wet seasonal savannah and It is characterized by a very variable structure, ranging from open grasslands (campo limpo), through open scrubland (campo sujo and cerrado sensu stricto) to dense woodlands (cerradão) (EITEN, 1994).
Several crops were introduced in this region, initially for food such as wheat, beans and rice, and in recent years have seen the introduction of species in order to evaluate their potential for adaptation and production of biodiesel, such as the oil seed crop Jatropha.

Jatropha curcas L., commonly known as the physic nut, is a perennial species, monoecious, belonging to the Euphorbiaceae family, the same as castor bean (Ricinus sp.), cassava (Manihot sp.) and rubber tree (Hevea sp.). It is a fast growing shrub, deciduous, sometimes reaching over 5 feet tall. It shows male and female flowers on the

${ }^{1}$ Empresa Brasileira de Pesquisa Agropecuária/Embrapa - Amazônia Oriental - Travessa Doutor Enéas Pinheiro - s/n - Cx. P. 48 - 66095-100 - Belém PA-Brasil - gurgel@cpatu.embrapa.br

${ }^{2}$ Empresa Brasileira de Pesquisa Agropecuária/Embrapa - Agroenergia - Brasília - DF - Brasil

${ }^{3}$ Faculdades Integradas/UPIS - Brasília - DF - Brasil

${ }^{4}$ Empresa Brasileira de Pesquisa Agropecuária/Embrapa - Meio-Norte - Teresina - PI - Brasil

Ciênc. agrotec., Lavras, v. 35, n. 6, p. 1122-1131, nov./dez., 2011 
same inflorescence, hermaphrodite flowers may also occur but at lower proportion. The inflorescences have higher number of male flowers, from 10 to 20 flowers per female flower. The fruits are ovoid capsules, 1.5 to $3.0 \mathrm{~cm}$ in diameter, trilocular, usually containing three seeds with one seed per locule. The seeds measure 1.5 to $2.0 \mathrm{~cm}$ long and 1 to $1.3 \mathrm{~cm}$ wide, representing between 53 to $79 \%$ of the fruit weight and oil content ranges from 33 to $38 \%$ (DIAS et al., 2007).

The adoption of physic nut as a culture to meet the Brazilian National Program for Production and Use of Biodiesel is due mainly to the high potential of grain yield and as a non-food species which crop management is consistent with the family farming profile (LAVIOLA et al., 2010). Despite the absence of improved cultivars and the lack information on production in different regions, it has been disseminated and implemented in several regions of Brazil (LAVIOLA; DIAS, 2008). For such species which is still undergoing domestication, the understanding of its phenology would contribute in the establishment of management practices for increasing productivity (AMORIM et al., 2009). It is also known that genetic materials behave differently in the same environment. Thus, phenological and climatological monitoring are important tools for predicting annual production, in order to identify the regulatory mechanisms of periodic growth rhythm and reproduction (ABDULLA et al., 2011; LEELA et al., 2011).

Among the morpho-agronomic traits related to production, plant height is important in the description of genotypes of a species, contributing to its diversity, and in the identification of the most promising accessions in a germplasm bank (LAVIOLA et al., 2010; Rosado et al., 2010). Moreover, it contributes to the description of plant morphophysiological conditions at time intervals and can be used to investigate the effect of ecological phenomena on the growth, such as the adaptability of a plant species in diverse ecosystems, competition effects, genotypic differences in productive capacity and the influence of agronomic practices on growth (BENINCASA, 1988). On the other hand, the number of inflorescences per plant and the number of ripe and dry fruits per plant are production components that interfere directly in the economic output (grain or oil). It is also important to relate these parameters with the climate variables to analyze the influence of physical environment variables on plant phenology.

Therefore, this study was undertaken to provide information on the phenology of three different genotypes of physic nut in the Brazilian Savannah biome during the 2009/2010 agricultural year, as well as relating the variationsx in growth and reproductive parameters to climate variables.

\section{MATERIAL AND METHODS}

The experiment was conducted with accessions of the physic nut germplasm bank established in the experimental area of Embrapa Cerrados in Planaltina, Distrito Federal, Brazil, at $15^{\circ} 35^{\prime} 30^{\prime \prime} \mathrm{S}$ and $47^{\circ} 42^{\prime} 30^{\prime \prime} \mathrm{W}$, at $1007 \mathrm{~m}$. The climate is classified as Aw, tropical with dry winter and rainy summer, according to Köppen-Geiger. The annual climatic variables are: $28.5^{\circ} \mathrm{C}$ maximum temperature, $17^{\circ} \mathrm{C}$ minimum and $22^{\circ} \mathrm{C}$ average. Relative humidity ranged from 91.3 to $46 \%$ with $73 \%$ average. Total rainfall for the period was $1,089.4 \mathrm{~mm}$. The soil is classified as Oxisol with high clay content.

The germplasm bank was established from seeds collected from isolated plants of physic nut between December 2007 and May 2008 at different locations, and from materials found in collections and plantations in Brazil. For this study, three accessions morphologically distinct CNPAE-102 (toxic, susceptible to powdery mildew), CNPAE-169 (non-toxic, susceptible to powdery mildew) and CNPAE-259 (toxic, resistant to powdery mildew) were used. Accessions with undetectable levels of phorbol ester in the grains were considered as non-toxic (DEVAPPA et al., 2010).

The quantification of phorbol esters (toxic compounds) was performed according to Makkar et al. (1997) with modifications to the extraction procedure. The ground seeds were placed on equipment by accelerated solvent extraction ASE 350 (Dionex, USA) using tetrahydrofuran as a solvent and then evaporated under nitrogen flow. The oily residue was transferred to a test tube of $10 \mathrm{~mL}$ and extracted four times with methanol $(1 \times 2$ $\mathrm{mL}+3 \times 1 \mathrm{~mL}$ ) and transferred to $5 \mathrm{~mL}$ volumetric flask, completed volume. The working solution was filtered to vial (PTFE Syringe VertiPure, $13 \mathrm{~mm}, 0.2 \mu \mathrm{m}$ ) and injected $(100 \mu \mathrm{m})$ in High Performance Liquid Chromatography (HPLC) Varian, using column C18 $250 \times 4.6 \mathrm{~mm}(5 \mu \mathrm{m})$ Vertisep UPS, room temperature (around $25^{\circ} \mathrm{C}$ ), ultraviolet detection (DAD) in the range from 200 to $340 \mathrm{~nm}$. To construct the standard curve was used standard 12myristate 13-acetate phorbol (Sigma, Cod.8139). The phorbol ester levels were $9.3 \mathrm{mg} / \mathrm{g}$ for access CNPAE-102 and $5.49 \mathrm{mg} / \mathrm{g}$ for access CNPAE-259.

The soil of the experimental area was corrected with limestone to raise the base saturation to $60 \%$. During the 2009/2010 agricultural year 300g per plant of a 20:5:20 fertilizer formulation was applied. The total dose was divided into three applications in November, January and 
March. Crop management practices, pest and disease control were carried out as routine maintenance of the germplasm bank (DIAS et al., 2007).

During a year period (August 2009 to July 2010), plant height was measured bi-weekly. Plant height (PH) was measured from the base of the stem to the top of the highest branch. To explain physiological growth during the phenological cycle, the nonlinear sigmoidal regression model with four parameters was used:

$$
\hat{y}=y_{0}+\frac{a}{1+\exp -\left(\frac{x-x_{i p}}{b}\right)}
$$

Where: $a=\mathrm{y}_{\max }-\mathrm{y}_{\min ;} b=$ adjustment parameter; $x_{i p}=$ Inflection point; $y_{0}=$ minimum point of the curve.

The inflection point $\left(\mathrm{x}_{\mathrm{ip}}\right)$ corresponded to the time (days) when maximum growth rate of each access was observed. The points of minimum curvature $\left(\mathrm{PC}_{\min }\right)$ and maximum $\left(\mathrm{PC}_{\max }\right)$ were calculated as previously reported by Venegas et al. (1998), using the parameters of nonlinear equations:

$$
\mathrm{PC}_{\text {min }}=\mathrm{x}_{0}-2 \mathrm{~b} \quad \mathrm{PC}_{\max }=\mathrm{x}_{0}+2 \mathrm{~b}
$$

The $P C_{\min }$ indicates the time in the curve when an expressive plant growth started and $P C_{\max }$ indicates when growth tended to stabilize. calculated:

Subsequently, the absolute growth rate was

$$
\text { AGR }=\frac{\left(\mathrm{H}_{2}-\mathrm{H}_{1}\right)}{\left(\mathrm{t}_{2}-\mathrm{t}_{1}\right)}, \text { where }
$$

$H_{1}$ and $H_{2}$ represent plant height of two successive samplings, and $t_{1}$ and $t_{2}$ represent the interval in days between the two samplings.

The number of inflorescences per plant (NIP), number of green fruit (NGF) and the number of yellow or dry fruits, considered as ripe (NRF). For these three reproductive variables, figures describing the oscillation of each variable during the phenological cycle were prepared (Figure 1).

The observations started on August 21 $1^{\text {st }}, 2009$ (day 1) and ended on July $16^{\text {th }}, 2010$ (day 330), 22 observations in total. The experimental plot consisted of five plants. The mean for each variable was calculated in order to correlate them with the climatic variables.
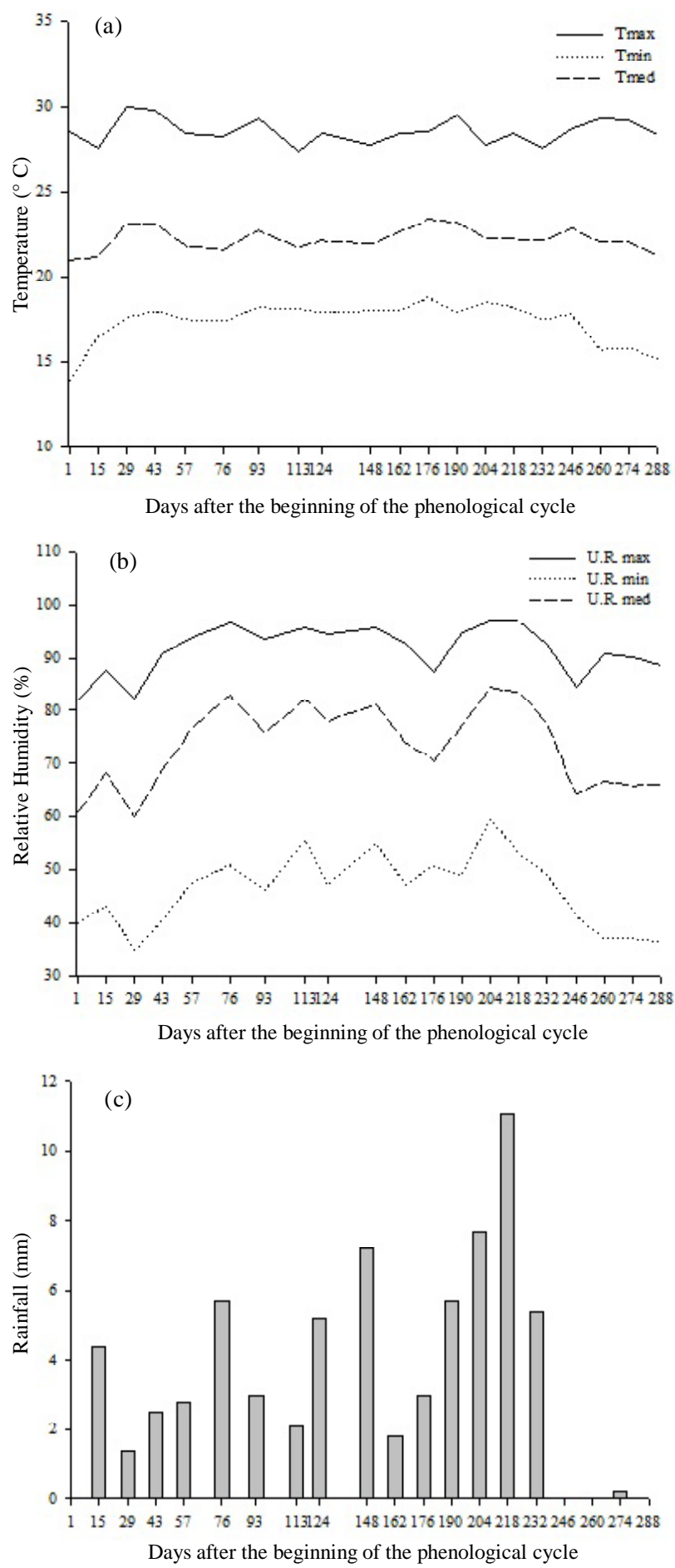

Figure 1 - Mean of the climatic variables measured biweekly during the phenological cycle. (a) Temperature $\left({ }^{\circ} \mathrm{C}\right)$. (b) Relative Humidity $(\%)$. (c) Rainfall (mm). 
During the evaluation of the phenological cycle, the climatic variables temperature and relative humidity were monitored daily (Figure 1) and the mean values related to the biweekly assessment were calculated. Daily rainfall was also recorded, calculating the mean precipitation for each period.

In order to correlate plant growth, flowering and fruiting with the climate, Pearson's correlation analysis between agronomic and climatic variables was conducted using the computer application Genes (CRUZ, 2004). For each variable, the mean for each period in which observation was carried out, in a total of 20 observations, was considered (days 1 to 288). At the last observation of climatic variables (day 288) plants were already quiescent and monitoring these variables during the period of 330 days was not necessary.

\section{RESULTSAND DISCUSSION}

The variation in the growth of the accessions over a phenological cycle, between August 2009 and July 2010, can be observed in Figure 2a. Accessions of physic nut presented distinct growth. CNPAE-102 showed higher growth throughout the period, an increment of $1.10 \mathrm{~m}$ and reaching a final height of $2.60 \mathrm{~m}$. The non-toxic accession CNPAE-169 showed lower growth in the period $(0.63 \mathrm{~m})$, reaching a final height of $1.85 \mathrm{~m}$ at the end of the phenological cycle. CNPAE-259 showed an intermediate growth behavior, reaching $2.52 \mathrm{~m}$ at the end of the period, growing $0.61 \mathrm{~m}$.

Among the accessions, CNPAE-169 showed a later development $\left(\mathrm{PC}_{\min }\right)$, initiating the vegetative growth 104 days (Dec $2^{\text {nd }}, 2009$ ) after the trial started, while CNPAE259 and CNPAE-102 started earlier, after 25 days (Sep 14 ${ }^{\text {th }}$, 2010) and 34 days (Sep 23 $3^{\text {rd }}, 2009$ ), respectively (Table 1). At the beginning of winter, as a deciduous plant, leaf abscission occurs and the plant remains quiescent, surviving on reserves and water stored in the trunk and branches until environmental stimuli trigger a new growth cycle (SATURNINO et al., 2005; ABDELGADIR et al., 2009). According to Larcher (2004), external stimuli may affect endogenous factors not only at cellular and molecular level, affecting the metabolic processes via transcription and translation, but also has a coordinating role throughout the plant body, which is performed by hormones which trigger changes in seasonal behavior of the plant. However, as shown in Figure 2a, the response to environmental stimuli is complex, with significant differences among genotypes in response to external factors.

Despite the difference among the genotypes on growth initiation, the accessions reached the end of the growing season a few days apart $\left(\mathrm{PC}_{\max }\right)$ with a maximum gradient of 7 days between CNPAE-102 and CNPAE-169.
Besides showing the lowest growth increment, CNPAE-169 (Figure 2a) also showed shortest growth time during the reproductive period (97 days of growth, while CNPAE-102 and CNPAE -259 grew for 160 and 171 days, respectively (Table 1). The values of the growth period were calculated by the difference between the $\mathrm{PC}_{\text {max }}$ and $\mathrm{PC}_{\min }$ of each accession.
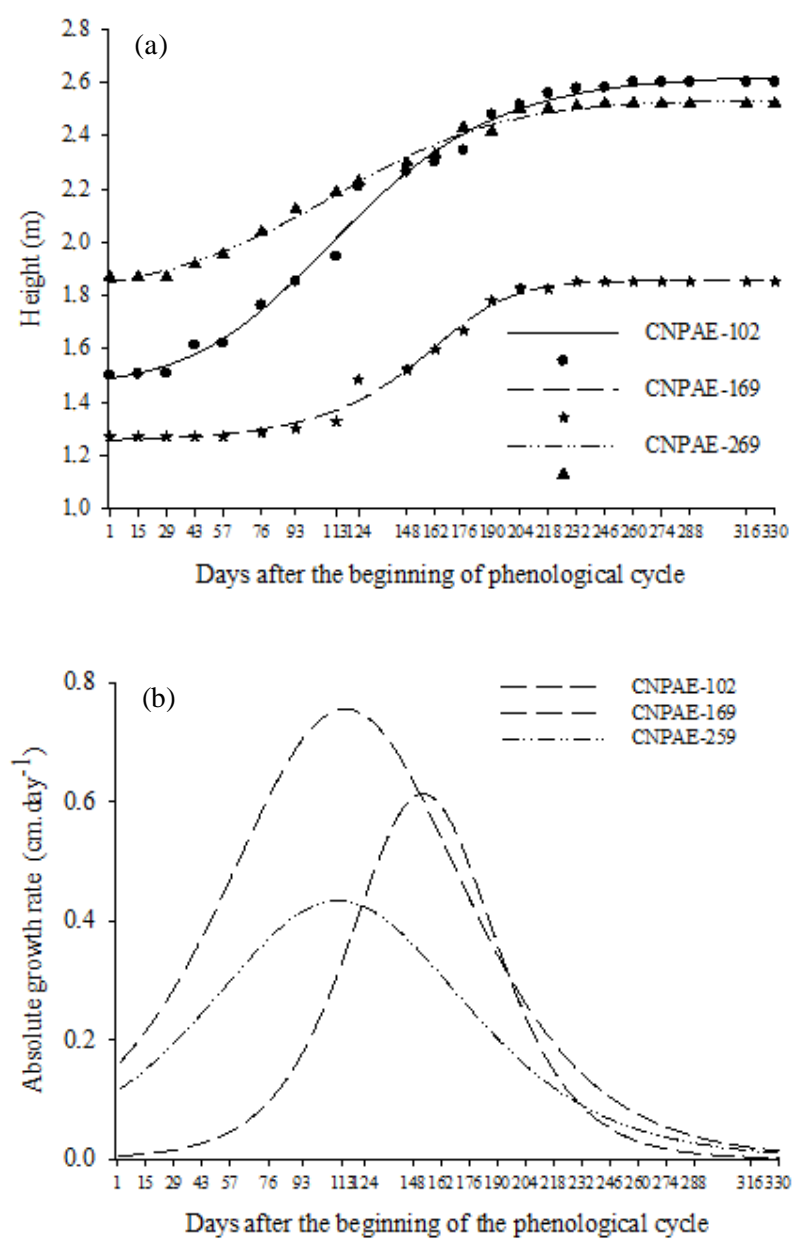

Figure 2 - Growth behavior of three accessions of physic nut as a function of time elapsed after planting. (a) Plant height. (b) Absolute growth rate.

The plants showed the highest growth rate (Xip) at 110 days (Dec $8^{\text {th }}, 2009$ ) for CNPAE-259, at 114 days (Dec $\left.14^{\text {th }}, 2009\right)$ for CNPAE-102 and 152 days (Jan $\left.21^{\text {st }}, 2010\right)$ for CNPAE-169, this last among all the later. In the studied period, CNPAE-102 showed the highest growth rate $(0.76$ $\left.\mathrm{cm} \mathrm{day}^{-1}\right)$ during the phenological cycle, followed by CNPAE - 169 (0.61 cm day $\left.{ }^{-1}\right)$ and CNPAE-259 (0.44 cm day $^{-1}$ ) (Figure 2b). 
Table 1 - Nonlinear sigmoidal regression equations for plant height in three genotypes of physic nut as a function of time after planting and growth parameters.

\begin{tabular}{cccccc}
\hline Genotype & Model & $\mathrm{R}^{2}(\%)$ & $\mathrm{X}_{\text {ip }}($ days $)$ & $\mathrm{PC}_{\min }$ & $\mathrm{PC}_{\max }$ \\
\hline CNPAE-102 & $\hat{\mathrm{Y}}=1.41+1.21 /(1+\exp (-(\mathrm{x}-113.74) / 39,96))$ & 99.29 & 114 & 34 & 194 \\
CNPAE-169 & $\hat{\mathrm{Y}}=1.26+0.60 /(1+\exp (-(\mathrm{x}-152.41) / 24.36))$ & 99.23 & 152 & 104 & 201 \\
CNPAE-259 & $\hat{\mathrm{Y}}=1.80+0.74 /(1+\exp (-(\mathrm{x}-110.16) / 42.69))$ & 99.44 & 110 & 25 & 196 \\
\hline
\end{tabular}

The differences in growth among accessions are explained by factors intrinsic to genotypes and such information should be considered in the use of genetic resources in the breeding program of the species. The analysis of growth demonstrated that CNPAE-169 has a lower tolerance to the cerrado environment. Since physic nut produces inflorescences in terminal buds, lower vegetative growth may be directly reflected in the production of fruits (SATURNINO et al., 2005; ACHTEN et al., 2010). Considering characteristics related to breeding programs, high productivity is followed by the absence of phorbol esters in seeds (DEVAPPA, 2010). Such character would allow the use of the press cake resulting from the extraction of oil as animal feed. In this sense, the use at commercial level of the non-toxic accession CNPAE-169 will require its recombination with early cycle and productive materials.

In Figure 3, variations on flowering and number of green and ripe fruits representing the reproductive period in the agricultural year can be observed. In general, the reproductive period characterized from the first flowering to fruit ripening, started after 29 days (Sep 18 $\left.{ }^{\text {th }}, 2009\right)$ with differences among genotypes in the intensity of flowering. The end of the reproductive period occurred around 316 days (Jun $7^{\text {th }}, 2010$ ), a total of 287 days. In the reproductive period plants are more susceptible to changes in the environment. Different aspects such as photoperiod, humidity, temperature, pollinators and dispersers, may be involved in variations in flowering and fructifications from one year to another. The understanding of the flowering and fruiting patterns of a species, provided by phenological surveys, is fundamental to unravel both the process itself and its reproductive success (FISCH et al., 2000).

Flowering is one of the most important phenological stages of the crop for oil production. The number of female flowers and their fertilization determine how many fruits and seeds will eventually develop. A continuous flowering results in a sequence of stages of reproductive development in the same branch, ripe fruit at the base, green fruit in the middle and flowers at the end of the branch (JUHÁSZ et al., 2009).
Figure 3 a shows two phases of flowering during the reproductive period. The first phase between 29 and 162 days, and the second phase between 162 and 330 days after planting. CNPAE-102 at 93 days of the first phase showed the highest number of inflorescences (16 inflorescences) and CNPAE-259 at 204 days showed the largest number of phase two, with 12 inflorescences. In the second phase of the flowering CNPAE-169 kept flowering for longer period when compared to the other accessions, a mean of ten open inflorescences could be observed after 204 days. The data presented in Figure 3 a characterized the early cycle of CNPAE-102 and the late cycle of CNPAE-169.

Physic nut produces flowers in terminal buds of branches grown in the current year and the production of new inflorescences is dependent upon new branches formation and growth. The drop in the rate of new inflorescences formation at 162 days might be explained by developing fruits in the same period, which competed directly with the formation of new inflorescences. During the reproductive phase of plant changes occur in the direction of metabolic drain, where the fruits have priority for photoassimilates hence restricting vegetative growth (ABDELGADIR et al., 2009). The fruits in development are so competitive, that monopolize most of the photoassimilates from surrounding leaves, as well as from more distant ones, causing a sharp decline in growth (ANWAR et al., 2010).

In Figure 3b, curves of the variation in the number of green fruit over the reproductive cycle can be observed. As occurred in the inflorescence, there were two peaks of fruit production. CNPAE-102 showed a peak in production of green fruit at 148 days which coincided with the decrease in the number of inflorescences in the first phase of flowering (Figure $3 a)$. The maximum number of green fruits produced at the end of the cycle also occurred at different time for each accession. CNPAE-102 at 148 days produced a mean of 71 green fruits, followed by the CNPAE-169 at 232 days with 83 fruits and CNPAE-259 at 246 days with 51 fruits. 


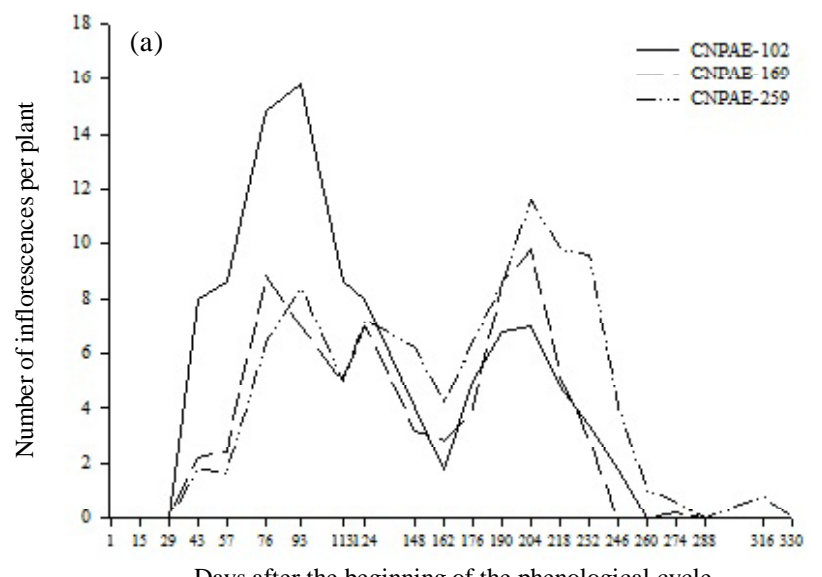

Days after the beginning of the phenological cycle
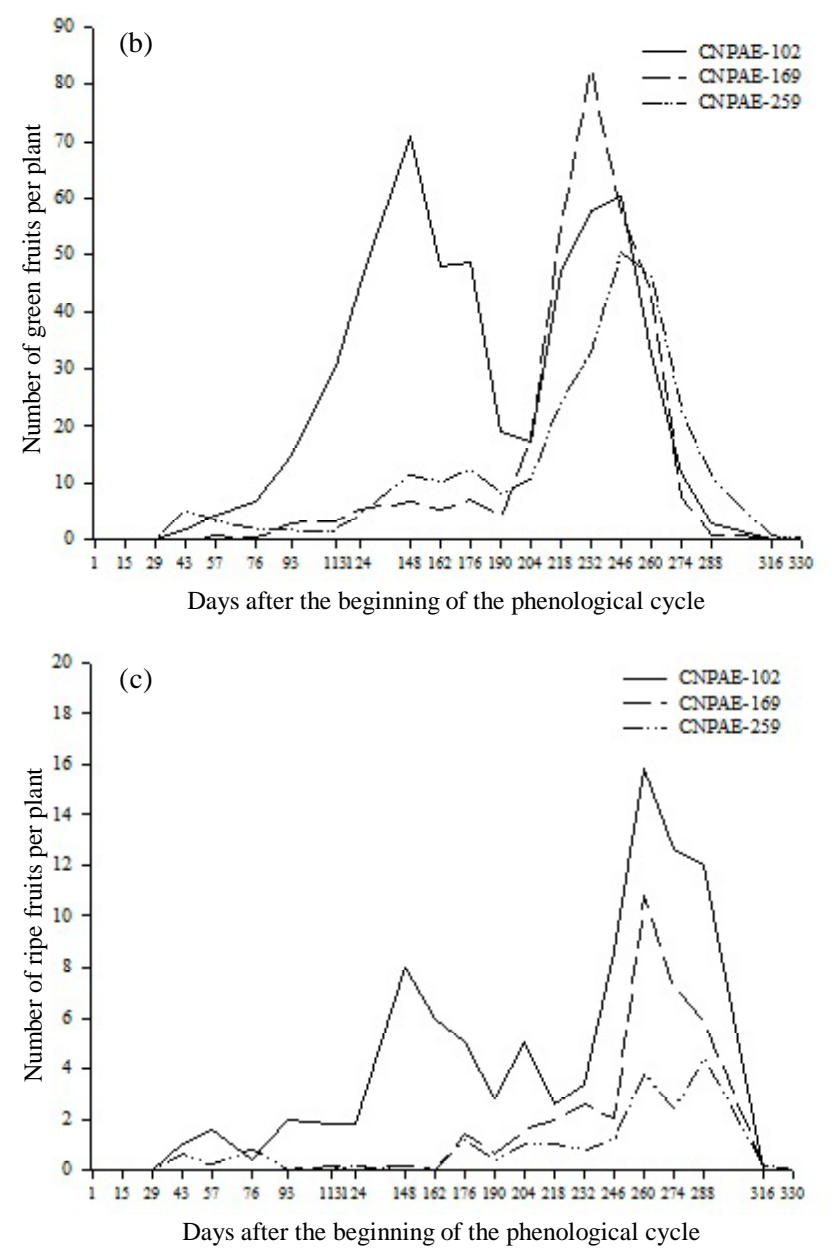

Figure 3 - Reproductive development of three accessions of physic nut as a function of time elapsed after planting. (a) Number of inflorescences per plant (NIP). (b) Number of green fruits per plant (NGF). (c) Number of ripe fruits per plant (NRF).
In the comparison of Figure 3a and Figure 3b, the results showed that although the late-cycle accessions CNPAE-259 and CNPAE-169 have a peak of about 8 inflorescences per plant on the first phase of flowering, a formation of a small number of green fruit was observed. A possible explanation for this is related to changes in the ratio of female/male flowers within the inflorescence, which is influenced throughout the year.

In general, for the accession CNPAE-102 the tendency of ripe fruit production also occurs in two peaks during the reproductive cycle (Figure 3c). The peak in the production of inflorescences was higher in the first phase of flowering (Figure 3a) but the production of mature fruits was higher in the second phase (Figure 3c). Moreover, when comparing the number of green fruit (Figure 3b) to number of ripe fruits (Figure 3c), the results show that only a part of developing fruits formed ripe fruits. One aggravating factor in the study environment that contributes to reducing fruit numbers was the severe occurrence of powdery mildew in the region (DIANESE; CARGNIN, 2008), especially for the susceptible CNPAE102 and CNPAE-169 variants. As the disease attacks the reproductive organs, it may have contributed to a large reduction of flowers and young developing fruits (CARELS, 2009).

The results of the phenological study conducted with these three accessions have identified the period in which the highest concentration of inflorescence, and subsequent fruit formation and development occurred. Such information is very important for the characterization of the genotypes cycle and for proper management of the plant. Furthermore, the present results underlie the identification of critical periods during the crop cycle, in which an environmental stress may cause more severe and sometimes irreversible damage. These periods should also be very well characterized in order to avoid or at least minimize damage to the plants and consequently to the production.

Phenological cycles of tropical plants are complex, with irregular patterns that are difficult to recognize, especially in short-term studies (BENCKE; MORELLATO, 2002). The results contributed in the understanding of the phenology of physic nut in the cerrado environment in the second year of development. However, the observations will continue to further stages of growth and reproduction of physic nut until adult plants.

Pearson's correlation analysis showed the relationship among the agronomic traits evaluated, as well as the direct influence of climatic variables on growth and development of physic nut genotypes (Table 2). For plant 
height $(\mathrm{PH})$ a positive correlation with the number of green and ripe fruits (1\% significance) in all three accessions was observed. But no correlation with climatic variables was found. The positive correlation of plant height with reproductive variables indicates that production is related to growth and, therefore, management practices for high rates of vegetative growth should be considered.

The number of inflorescences per plant (NIP) showed significant correlation with number of ripe fruits (NRF) only for accession CNPAE-102 and the correlation was negative. These results indicate that not only the number of inflorescences will determine the fruit production but other factors may play different roles in flower fertilization, development of the reproductive organs and contributing to the number of fruits.

The climatic variable that best correlated positively with the agronomic traits was the minimum temperature $\left(\mathrm{T}_{\min }\right.$, Table 2$)$. This variable determined the emergence of a higher number of inflorescences, being associated, in general, to the relative humidity for the formation of new inflorescences (NIP). The induction of inflorescences is the first component of production observed during the phenological cycle and the other components depend upon it. NGF and NRF were not explained by climatic variables, since after the formation of the inflorescences, other factors such as the occurrence of diseases, insects, among others, might contribute more effectively in the expression of characters.

According to Larcher (2004), temperature has an indirect influence on growth and on the course of development (due to its quantitative effect on the energy supply from the basal metabolism and the biosynthesis) and direct effects via regulatory processes, such as thermoinduction, thermoperiodism and thermomorphism. A study by Laviola et al. (2007) reported that the cycle of coffee trees, as well as the duration of reproductive phases was influenced by the altitude of cultivation, and the longest cycle was associated with occurrence of lower temperatures at higher altitudes.

When comparing Figure 3a with Figure 1a, the formation of new inflorescences started after the 29 days, when the minimum temperature was $19.7^{\circ} \mathrm{C}$. A significant drop in the inflorescence formation was observed after 246 days of evaluation, when the minimum temperature was $18.6^{\circ} \mathrm{C}$, at which time reductions in $\mathrm{RH}$ and rainfall also occurred (Figures $1 \mathrm{~b}$ and $1 \mathrm{c}$ ). These results indicate that physic nut requires a minimum temperature of above $18^{\circ} \mathrm{C}$ for new flower bud formation and development followed subsequently by fruit production. Knowledge of the minimum temperature is important for the establishment of climate and soil suitability maps for commercial cultivation of perennial species. In the case of the physic nut, whose inflorescences develop from terminal buds (not axillary), such information is even more relevant because in regions where the minimal temperature remains below $18^{\circ} \mathrm{C}$ for several months the plants will have a shorter reproductive period, directly affecting the final production. However, this is a particular study for the Brazilian Cerrado and must be expanded to other regions of the country in order to confirm the results observed in this work. 


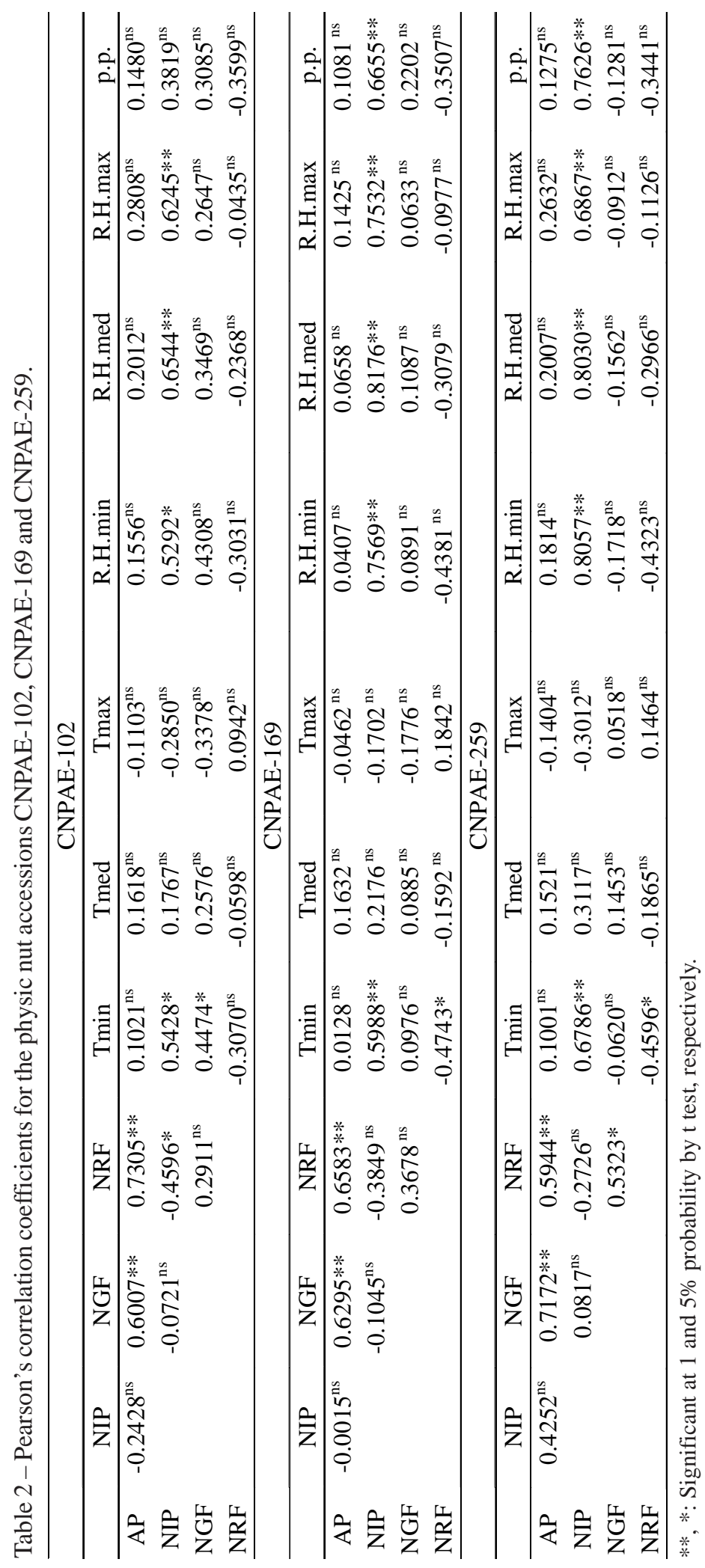

Ciênc. agrotec., Lavras, v. 35, n. 6, p. xx-xx, nov./dez., 2011 


\section{CONCLUSIONS}

The accession CNPAE-102 shows the highest growth rate $\left(0.76 \mathrm{~cm}\right.$. day $\left.^{1}\right)$, with $1.10 \mathrm{~m}$ increment in height and final height of $2.60 \mathrm{~m}$. CNPAE-169 shows the lowest increment in height $(0.63 \mathrm{~m})$, reaching final height of $1.85 \mathrm{~m}$.

The accessions CNPAE-102 and CNPAE-259 show early cycles and CNPAE-169, late cycle.

Minimum temperature is the climatic variable that determines the most inflorescences.

\section{ACKNOWLEDGEMENTS}

To FINEP and CNPq for financial support.

\section{REFERENCES}

ABDELGADIR, H. A.; JOHNSON, S. D.; VAN STADEN, J. Effect of foliar application of plant growth regulators on flowering and fruit set in Jatropha curcas - A potential oil seed crop for biodiesel. South African Journal of Botany, v. 75, n. 2, p. 391-391, apr 2009.

ABDULLA, R.; CHAN, E. S.; RAVINDRA, P. Biodiesel production from Jatropha curcas: a critical review. Critical Reviews in Biotechnology, v. 31, n. 1, p. 53-64, Mar 2011.

ACHTEN, W. M. J. et al. Biomass production and allocation in Jatropha curcas L. seedlings under different levels of drought stress. Biomass \& Bioenerg, v. 34, n. 5, p. 667-676, may 2010.

AMORIM, I. L.; SAMPAIO, E. V. D. B.; ARAUJO, E. D. Phenology of woody species in the Caatinga of Serido, RN, Brazil. Revista Arvore, v. 33, n. 3, p. 491-499, may-jun 2009.

ANWAR, F. et al. Jatropha Curcas seed oil as a viable source for biodiesel. Pakistan Journal of Botany, v. 42, n. 1, p. 575-582, jan. 2010.

BENCKE, C. S. C.; MORELLATO, L. P. C. Comparison of two methods of plant phenology estimation, their interpretation and representation. Revista Brasileira de Botânica, São Paulo, v. 25, n. 3, p. 269-275, set. 2002.

BENINCASA, M. M. P. Análise de crescimento em plantas: noções básicas. Jaboticabal: FUNEP, 1988. 42 p.

CARELS, N. Jatropha curcas: A Review. Advances in Botanical Research, v. 50, p. 39-86, 2009.
CRUZ, C. D. Programa Genes - Programa para análise estatística, biométrica e multivariada de dados quantitativos e moleculares. Versão 2004. Disponível em: <http://www.ufv.br/dbg/genes/genes.htm>. Acesso em: set. 2010.

DEVAPPA, R. K.; MAKKAR, H. P. S.; BECKER, K. Jatropha Toxicity. A Review. Journal of Toxicology and Environmental Health-Part B-Critical Reviews, v. 13, n. 6, p. 476-507, 2010.

DIANESE, A. C.; CARGNIN, A. Ocorrência de Oidium sp. em pinhão-manso. Brasília, DF: Embrapa Cerrados, 2008. 15 p. (Embrapa Cerrados. Documentos, 231).

DIAS, L. A .S. et al. Cultivo de pinhão-manso (Jatropha curcas L) para produção de óleo combustível. Viçosa: UFV, 2007. v. 1.40 p.

EITEN, G. Vegetação do Cerrado. In: PINTO, M. N. (Org.). Cerrado: caracterização, ocupação e perspectivas. Brasília: Ed. Universidade de Brasília, 1994. p. 17-73.

FISCH, S. T. V. et al. Fenologia reprodutiva de Euterpe edulis Mart. na Mata Atlântica (Reserva ecológica do Trabiju, Pindamonhangaba-SP). Revista Biociências, Taubaté, v. 6, n. 2, p. 31-37, 2000.

JUHÁSZ, A. C. P. et al. Floral biology and artificial polinization in physic nut in the North of Minas Gerais state, Brazil. Pesquisa Agropecuária Brasileira, Brasília, v. 44, n. 9, p. 1073-1077, set. 2009.

LARCHER, W. Ecofisiologia vegetal. São Carlos: RiMa, 531p., 2004.

LAVIOLA, B. G. et al. Genetic parameters and variability in physic nut accessions during early developmental stages. Pesquisa Agropecuária Brasileira, Brasília, v. 45, p. 1117-1123, 2010.

LAVIOLA, B. G. et al. Assimilates allocation in fruits and leaves of coffee plants cultivated in two altitudes.

Pesquisa Agropecuária Brasileira, Brasília, v. 42, p. 1521-1530, 2007.

LAVIOLA, B. G.; DIAS, L. A. S.. Nutrient concentration in Jatropha curcas L. leaves and fruits and estimated extraction at harvest. Revista Brasileira de Ciência do Solo, Campinas, v. 32, p. 1969-1975, 2008. 
LEELA, T. et al. Morphological, physico-chemical and micropropagation studies in Jatropha curcas L. and RAPD analysis of the regenerants. Applied Energy, v. 88, n. 6, p. 2071-2079, jun. 2011.

MAKKAR, H. P. S. et al. Studies on nutritive potential and toxic constituents of different provenances of Jatropha curcas. Journal of Agriculture and Food Chemistry, Easton, v. 45, p. 3152-3157, 1997.

ROSADO, T. B. et al. Molecular markers reveal limited genetic diversity in a large germplasm collection of the biofuel crop Jatropha curcas L. in Brazil. Crop Science, Madison, v. 50, p. 1-11, nov./ dec. 2010.

SATURNINO, H. M. et al. Produção de oleaginosas para o biodiesel. Informe Agropecuário, Belo Horizonte, v. 26, n. 229, p. 44-74, 2005.

VENEGAS, J. G.; HARRIS, R. S.; SIMON, B. A. A comprehensive equation for the pulmonary pressurevolume curve. Journal of Applied Physiology, Bethesda, v. 84, p. 389-395, 1998. 